\section{H A P T E R

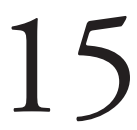

\title{
Buried Treasure: A Business Librarian's Insights on Finding the Evidence
}

Roye Werner

\begin{abstract}
This chapter offers my perspective as a professional librarian and former manager on accessing the research evidence in the business and management fields. I describe the barriers faced by managers, students, and scholars in locating and reading the peer-reviewed literature: its scattered placement, varying formats, controlled access, and swiftly changing environment. I explore how those roadblocks are being overcome, and I offer practical recommendations for both managers and researchers on what they can do today to bring that evidence to light.
\end{abstract}

Key Words: peer-review; academic journals; electronic, on-line sources; evidence ; search; libraries; databases

The following is a true story:

Congratulations-you've just been promoted to manager. After years of hard work, you're now the department head. People report to you. You have products and services to deliver and customers to satisfy. How do you learn to manage all this, dayto-day and for the long term? With luck, you've had some training. You might find yourself a good mentor or two, and perhaps someday you'll get a chance to enroll in executive education at the local business school. However, those are future, and only partial solutions. Wait a minute! There must be a multitude of answers and good advice available in the thousands of business books and articles published each year. Don't forget the assault of blogs, wikis, web sites, even twitter feeds. How do you find those answers? Once you do, can you actually get hold of and understand them? And most importantly, how do you know what is good?

This was the situation I found myself in when, in 1998, after eight years as a business librarian, I became the head of my department: the branch of Pittsburgh's public library that provides business-and finance-related information to residents, employees, and companies in Allegheny County, Pennsylvania. Suddenly in charge of 20 staff members (professional librarians as well as library assistants and clerks,) a budget, planning, customer service-I needed to study up on how to be the person in charge, and fast.

You would think that as a business librariansurrounded by books, journals, and computers all filled with the works of experts, much of which I and my staff had selected and organized-I would know just what to do. However, amid the pressing demands of proposals, interviews, meetings, reports, forms, assessments, conflict resolutions, and so on-finding just the right coaching at the right time was as overwhelming for me as for any new manager. Given the time pressure, what drew me most strongly were book titles. I succumbed to the appeal of the One-Minute Manager (Blanchard and Johnson, 1982)-though I put it down again pretty quickly. It's also how I found First, Break All the Rules (Buckingham and Coffman, 1999)-a book from the Gallup Organization whose findings 
I ultimately came to trust and use, not least because the first chapter describes the large amount of evidence behind them. In all honesty, it never occurred to me to search for research articles, let al.ne metaanalyses on specific topics. If this is what it was like for me, then how is it for other managers?

This chapter offers my perspective as a professional librarian on accessing the research evidence related to business and management. I describe the roadblocks that the layperson and typical manager would commonly face in trying to answer a practice question using this evidence, and also the challenges that even students and scholars confront in locating this research. I then discuss ways to surmount those roadblocks in the short term, and what might be done to reduce them further on. As my experience and research has been Western-focused, this will cover the situation as I see it in the English-speaking and European world; certainly similar situations exist in Asia, South America, and Africa, but that coverage awaits another author.

\section{Roadblocks}

It wasn't until I became a librarian at a university that I discovered the range, promise, and complexity of scholarly research and recommendations on management issues. The density of language in that research, and its sometimes tenuous relation to the problems managers face, has been discussed in numerous articles (Cascio, 2008; Markides, 2007; Sutton, 2004; Vermeulen, 2007). Those problems aside, there is another formidable obstacle to contend with: the complex configuration (primarily in cyberspace) of that body of knowledge- how it is stored, how to identify what is relevant to a particular question, and who can get to it. As healthcare manager John Zanardelli says in his chapter in this handbook, "It is often challenging and may be near impossible to find quality evidence." Here I'll attempt to explain why that is by describing those barriers, after which I'll explore the ways they can be circumvented, more of which are opening up each day as a result of new technologies, attitudes, and initiatives.

As a nod to all those practitioner-aimed books that flow into public libraries and airport bookstores, let's examine the three roadblocks to finding the evidence.

\section{Roadblock 1: Chaos}

The first roadblock to finding the evidence is the way it is currently located and configured. At the moment, the peer-reviewed research articles and books that could form the basis for evidence-based decision-making are scattered over a diverse and disordered universe of publications. These articles and books are in numerous formats: print, microfilm and microfiche, CD-ROMs, and on the Internet.

In the past, of course, the printed and bound academic journals and books that contained all scholarly knowledge were kept and accessed exclusively in research libraries and in the private collections of individual subscribers. To find articles on a particular topic, the only tools available were print indexes, also only in libraries; in the case of business literature, those were the Industrial Arts Index (19131957), Business Periodicals Index (1958 - present), and starting in 1972, the Social Sciences Citation Index. Those collections and indexes still exist, in print, in microforms, and even in electronic storage devices like floppy discs or CD-ROMs, though they are rapidly moving to off-site storage. (These facilities are now sometimes euphemistically called the "heritage collection.")

However, with warp speed once we entered the Internet Age, the great majority of those articles, past and present, leaped into cyberspace, along with a much smaller but increasing number of books. They now have extraordinary reach through their potential availability over any Internet line. That reach is compromised by a mix of controls, costs, and compartmentalization. For instance, there are 89 academic journals specializing in management research listed in the "management" category in ISI Web of Knowledge, a database containing citations for most international scholarly literature. (This is in addition to many other academic journals in marketing, leadership, strategy, etc.) The articles in those journals are made available over the Internet in various ways. One way, of course, is by direct subscription-a costly and time-consuming arrangement, for both individuals and libraries. It is also rare that all articles of interest will be contained in a few publications, and no person or library can subscribe to everything. Most of the significant business and management scholarly journals have been acquired by a small group of publishers, of which the principal ones are: Elsevier (Science Direct,) Wiley-Blackwell (Wiley Interscience,) Emerald, and SAGE. This can be helpful in terms of consolidation and standardization, since they provide across-the-board searching systems (though only for titles they own and via web sites that they control.) However, the bad news, for libraries at least, is that the dwindling competition gives these publishers more monopolistic pricing power. 
A more efficient way to access these articles is through subscription-based databases, which have contracts with the journals' publishers. These databases also offer searching systems that can locate articles on a particular topic. The most widely used are: ABI/INFORM (from ProQuest); Academic Source Premier/Complete and Business Source Premier/ Complete (from EBSCO); Academic OneFile, General Businessfile and Business \& Company Resource Center (from Gale/Cengage); and JSTOR (from ITHAKA). The holdings within these databases differ widely - there is much unique but also overlapping coverage. They also often contain a mix of practitioner, mainstream, and academic publications (though most make some effort to distinguish which is which). Furthermore, the holdings are a moving target: titles are constantly dropped and added, dates are expanded and cut back. Some of these databases have exclusive contracts with high-demand publications-for instance, EBSCO currently has a lock on the Harvard Business Review. Many journals are not fully available in any database, and must be subscribed to directly. Added to this, the entire publishing industry is undergoing a radical transformation, making the entire situation temporary and unstable.

Poised on the outer edge of the world of official refereed publications, there are other sources for reputable research output in the management field. Working papers and other forms of prepublication efforts are made available on the web through sites such as the Social Science Research Network (www.ssrn.com) and Research Papers in Economics (repec.org), and increasingly through authors' websites and institutional repositories. There are also research and professional organizations that publish their own books and journals — both academic, like the Academy of Management, INFORMS, Cornell's International Labor Relations School, the Academy of Human Resource Development; and practitioner-oriented, like the Conference Board, the American Management Association, and the Society for Human Resource Management. Abroad, there are the Advanced Institute of Management Research (UK) and the European Foundation for Management Development (Belgium). Finally, there are management-oriented consulting firms, like McKinsey, Gartner, and Bain \& Co. The output of these organizations is readily accessible to members or clients, but for nonmembers they are often exorbitantly expensive and sometimes unavailable at any price.

Books are the other important repository of management research and knowledge, and their landscape is quite different from that of journal publishing. First, the electronic availability of academic books is proceeding more slowly than that of journal articles (Housewright \& Schonfeld, 2008). In academic libraries, the books that tend to be acquired as e-books are not research monographs, but textbooks, reference works, multimedia, and out-of-print books (Tedd, 2005). Publishers, also, are still issuing their scholarly books primarily in print form. A look at the book purchasing options from Baker \& Taylor's YBP Library Services-a major purchasing service for academic librariesshows that of 371 titles classified both as "advanced academic" and "management" published between 2008 and 2010, only 64 were available as e-books as of this writing. Even at Amazon, which has put a supreme effort into supplying e-books for its Kindle book reader, its "Management Science" categoryadmittedly mixing the practitioner books with scholarly ones-offers over 9,400 printed titles compared to 936 Kindle titles. Thus, the primary place at the moment to get hold of book content is not over the Internet, as in articles, but still in libraries and in bookstores (or purchased over the Internet, but still in a physical package). Although, with the milestone recently reached at Amazon, where by July of 2010 more electronic books were being sold than print ones (Miller, 2010), this situation is quickly evolving.

Second, although there is a recognizable group of book publishers that reliably submit their books to the peer review process, notably university presses and others such as Routledge, SAGE, Blackwell, and Palgrave Macmillan, the boundaries are becoming blurred. Some professors go commercial, availing themselves of the greater marketing power of publishers like Penguin or HarperCollins. This would make it difficult for a random reader to know in which corner-popular or scholarly-a particular book stands, unless that reader has learned how to detect the signs of a solid underpinning of research, such as scholarly citations, academic credentials for the author, and the use of scientifically determined evidence. At the same time, university presses, under increasing financial pressure, must base decisions on what is viable in the marketplace, and so a greater number of well-researched manuscripts never see the light of day (Wilbourne, 2001).

\section{Roadblock 2: Invisibility}

The second roadblock consists of difficulties in locating research relevant to your needs in this confusing landscape. The first thing to consider is how 
to even learn of its existence. This trove of carefully researched, compiled and vetted knowledge is largely invisible to varying degrees, depending on whether you are a manager, a student, or a professor.

It seems almost hopeless for the byzantine and unadvertised research landscape described earlier to compete with the marketing juggernaut that ubiquitously offers up the likes of Who Moved My Cheese? (Johnson, 1998) and Fast Company magazine, particularly for managers. The diffusion of business books and magazines is a big industry, as is clearly seen in the thriving "business" sections in airport and other bookstores (Furnham, 2000,) not to mention public libraries. Amazon has almost 340,000 books in its "Management $\&$ Leadership" category, and The Five Dysfunctions of a Team (Lencioni, 2002), literally a fable, is currently at the top of its "Management Science" list. For executives who need help wading through all those titles, several online services like 800ceoread.com and Soundview Executive Book Summaries (summary.com) have sprung up to deliver commentary, podcasts, summaries, and selections. The FT Press, a unit of the Financial Times, now presents "insights from great business minds" in e-snippets that are so short they can be read in 10 minutes on a cell phone and are priced under $\$ 3$ (Rich, 2010). Any Google search will turn up a veritable Babel of practitioner-oriented magazines, reports, and newsletters. Small wonder that multiple studies have shown that managers read little academic research (Terpstra \& Rozell, 1997; Kay, 2001; Rynes, Colbert, \& Brown, 2002; Case, 2008). For evidence-based management to find some visibility among all that glitz will be a daunting challenge. This is not to say that all of popularly available management advice is, to quote Bob Sutton, "crap" (Sutton, 2006), but that it's hard for the nonacademic to distinguish opinion from science unless they know to look for citations to scientific research.

Students and professors make use of the scholarly literature at their disposal in varying degrees. Professional journals in academic librarianship are filled with laments about how few campus denizens use databases as opposed to the open web (Cason \& Van Scoyoc, 2006; Griffiths \& Brophy, 2005), inspiring a campaign led by academic libraries to promote "information literacy" (more on this below). When I give lectures on business information resources to both undergraduate and MBA students, their surprise and even wonder at what has been for years right under their noses shows that mere availability is not enough. Guidance and promotion are also needed, if students are to "search for the best available evidence," a key component of evidence-based teaching (Rousseau \& McCarthy, 2007). Professors, however, especially junior faculty, are gradually making the transition from their traditional methods-scouring journals and keeping in touch with collegial networks - to a dependence on electronic information resources (Shen, 2007; Housewright \& Schonfeld, 2008).

Even for those aware of the great body of research that exists, there is the challenge of learning to search through terabytes of electronic text. The other evidence-based fields of medicine and education have a much easier time, since each has its research consolidated in one dedicated overarching database: PubMed and ERIC, respectively (both funded by the government). In those cases, there is only one system to learn, and one route to finding the material. However, in the case of business research, every database and most of the publishers described earlier provide their own searching and retrieval systems, which are maddeningly unique and often opaque. Even seasoned scholars report significant frustration and difficulty when trying to navigate through these systems (Institute for the Future, 2002). Most universities have tried to address this problem of multiple search environments by purchasing and providing a "federated search" application, with names like MetaLib and WebFeat-systems that can search through multiple commercial databases as well as other text-based digital collections and catalogs simultaneously. These, however, are far from perfect and suffer from numerous usability problems (Gibson, Goddard, and Gordon, 2009. The database ISI Web of Knowledge, though not a federated searching product, provides essentially the same function for scholarly literature, as it searches through and delivers citations from over 12,000 academic publications. Using it is so complicated that it offers lengthy online tutorials. More recently, libraries have been acquiring newly developed "discovery services," such as Summon and Worldcat Local, which create Google-like search engines for all library-provided content.

Google is addressing this difficulty with characteristic aplomb. Google Scholar (scholar.google. com) is, in fact, a free federated searching tool, available to anyone with an Internet connection; it looks through the contents of thousands of scholarly journals, papers, and books. (It has recently added patents and legal documents.) As one might expect, it is far more intuitive and easier to use than the commercial products. It provides, for the most part, 
only access to citations, linking to a publisher's site where the content can be purchased. (There are two exceptions to this. One is that, for anyone attached to a university, Google Scholar is usually linked to the subscriptions that the university has paid for, and so there is a seamless connection to the full content for those who are on campus or who are using the off-campus Internet access application. Another is that Google—in its customary magical way-can occasionally find a link to content even when it is protected, such as to a prepublication document, to a research repository, or to a professor's personal web site.)

\section{Roadblock 3: Inaccessibility}

The third obstacle is actually getting hold of the articles and books themselves. Savvy and determined managers (or those who have read this chapter) might use Google Scholar to find exactly the right article-even a meta-analysis or systematic review-to address a particular management problem. Will those managers be able to get their hands on it? Databases are like gated communities; access to the full text of all of these articles is severely limited by ownership rights, subscription or pay-per-view systems, and intellectual property controls.

For individual managers, the barrier is significant. Although larger corporations in the past had their own corporate libraries, those have been disappearing for decades (Matarazzo \& Pearlstein, 2007; Housewright, 2009). The cost of databases and subscriptions to individuals and small businesses can be prohibitive; for instance, the Journal of Organizational Behavior costs $\$ 363$ yearly for individual subscribers, who can only get it in print. Single articles can be purchased from most publications, but that cost is also a deterrent- $\$ 31.50$ per article from Science Direct, for example. Databases cost tens of thousands of dollars. The relation of scholarly research to practitioner publications has been compared to haute couture vs. prêt-a-porter (Alvarez \& Mazza, 1998)—elite and expensive on the one hand, accessible and affordable on the other. Studies showing that managers value "ease of use and general accessibility" in their information sources (Terpstra \& Rozell, 1997) reveal that these obstacles can be fatal to hopes of scholars reaching practitioners.

For students and professors, who have campus connections, university libraries have undertaken the role of acquiring and managing these subscriptions, but, especially lately, they are under severe budgetary pressure to cut back, even as costs increase each year (Oder, 2009). Furthermore, the databases provide far from unlimited access to begin with, often enforcing "embargoes"- - meaning that a certain number of months or years of current content is blocked. Online subscriptions to individual titles do provide current content, but exact heavy extra costs for early issues. Only the most well-endowed university libraries can afford to provide unfettered immediate access to all management publications. (Although for those willing to wait, the interlibrary loan system can usually deliver a needed article or book.)

\section{New Forms of Access}

Roadblocks can be overcome, so let's look at the ways that we-students, researchers, managers, and librarians - can now or in the near future get our hands on good, solid evidence in books and journals, in meta-analyses and systematic reviews, and in handbooks and encyclopedias. We hope for a quick evolution of handy and authoritative tools emerging from an EBMgt collaborative (Rousseau, 2007), but even in an optimistic scenario, those will probably be a few years in the making. In the meantime, we are not without resources.

Where you are-working in a large corporation, affiliated with a university, starting up your own business, even what city you live in - makes a difference in your access rights. For those affiliated with universities, access to subscription journals and databases is generally a given. However, those who are not might be surprised to find that a free library card from their local public library will give them online access to some of the better business and management databases. Major cities have multiple offerings, but even smaller cities, such as Hartford, Birmingham, Worcester, and Cincinnati, provide at least one of the major business research databases (although, sadly, the recent financial crisis is causing some libraries to cancel those subscriptions.) In addition, alumni offices are starting to provide similar access to their university's graduates; a 2006 report showed that 18 percent of 102 top universities surveyed already offered this (Wells, 2006,) and if queries by the MBA students that I see are any indication, there is a growing demand for this service.

As mentioned earlier, Google is working on this as well, and since that is where most people go for information online today (Marshall, 2009), this is a good thing. Google Scholar (scholar.google.com) and Google Books (books.google.com) are not the whole answer, but as meta-searching tools, they are 
immediately accessible, simple to use and constantly evolving. A simple search: "meta-analysis pay for performance" in Google Scholar turns up a number of good peer-reviewed possibilities. For those not university related, of course, it will not lead to the article itself, but the abstract, readily available, may be almost enough. The same search in Google Books also provides some excellent sources, one of which is the Blackwell Handbook of the Principles of Organizational Behavior, edited by Edwin Locke (2000). My search led directly to the chapter "Pay for Performance" by Cathy Durham and Kathryn Bartol (both management professors,) and provided the scanned entire text of that chapter, references and all (Durham \& Bartol, 2004). Due to copyright restrictions, the texts available from Google Books will be missing numerous pages, and the results of searches like this will be serendipitous and changeable from day to day, but they will certainly provide something of substance. By 2009, Google Books offered the searchable contents of over 10,000,000 entire books, and is making plans to provide "free access to full texts at a kiosk in every public library in the United States." (Brin, 2009).

Two recent movements spearheaded by university libraries are attempting to have some impact on some of these issues. First, the growing "information literacy" movement is aimed at teaching students at all levels (Bennett, 2007), not only about "the practical skills involved in effective use of information technology," but also about "the nature of information itself, its technical infrastructure and its social, cultural, and even philosophical context and impact." (Shapiro \& Hughes, 1996). This will hopefully address both the "difficult to search" and "not knowing what exists" problems, in that students who go on to the business world will have an educated sense of what information has true value, where it is, and how to get to it. Hopefully, this will instill in students the motivation and skills they need to look for and find useful evidence in their post-graduate careers.

Second, the "Open Access" movement encourages the authors of scholarly research to make their work freely accessible to the public, eliminating the stranglehold that scholarly publishers have on the kind of management articles discussed here (Suber, 2007). In 2008, in the biomedical field, this was given a boost by the National Institutes of Health policy requiring any research that is NIH-funded to be freely available - and so liberating a large quantity of those articles from fee-based status. Now the Federal Research Public Access Act of 2009
(H.R.5253, S.1373), requiring all governmentfunded research to follow the same requirements, is being considered in Congress, and holds promise for liberating many more publications in all fields. Entire journals are being born as peer-reviewed open-access publications; an example in the business field is BuR-Business Research (www.business-research.org/) that was begun in 2008 by the German Academic Association for Business Research. This migration to unrestricted online access will probably grow as scholars see the advantages of vastly increased exposure of and citations to their writings as a result (Odlyzko, 2002) and develop their bargaining power in establishing contracts with the publishing industry. If this phenomenon becomes more standard for academic publications, the restrictions on access will lessen considerably. In the meantime, many organizations are moving ahead in the race to provide informational guidance on management issues.

The effort to gather, consolidate, and compress management knowledge on specific topics into readable and authoritative form is proceeding on numerous fronts, some profit-oriented and some not, and with varying degrees of accessibility and trustworthiness. For instance, the Society for Human Resource Management now offers 11 reports that are "effective practice guidelines," which present "important research findings in a condensed, easy-to-use format for busy HR professionals" (www.shrm.org). These are handy, attractive, and quickly downloadable booklets of around 50 pages, covering topics like "Recruiting and Attracting Talent," "Employee Engagement and Commitment," and "Performance Management" performance management-and free to anyone with a computer.

There is also a growing number of handbooks and encyclopedias on business and management. These are works that strive to present concepts and findings in a concise and authoritative way; some of them have been published in print form for years, but their recent electronic publication and corresponding publicity blitz makes them far more visible, though with price tags that would generally limit their reach. Scholarly publishers Oxford University Press (Oxford Handbooks Online-Business \& Management), Wiley/Blackwell (Blackwell Reference Online-Business and Management), and SAGE (various business e-encyclopedias) attempt to do this based on academic research. The more commercially oriented and relatively inexpensive Business: The Ultimate Resource, in its 2nd 
edition from British publisher A.C. Black is a hefty, mixed mélange of solutions, recommendations, and best practices "from the world's top practitioners, thought leaders, and academics." (A new edition is scheduled for 2011.)

Long-time academic publisher Emerald-www. emeraldinsight.com—which claims to be the "world's leading publisher in management research," has initiated an ambitious foray into resolving the research-practice gap. As they clearly state on their web site: "To make the world better managed means a bridging of the gap between the world of research and the world of application. Emerald's mission is to make this a reality" (first.emeraldinsight.com/ about/philosophy.htm). They have developed a number of information packages specifically targeted at business students, teachers, and managers. These include: "Emerald Management Reviews," abstracting articles (both their own and other publishers') from what they describe as "the top 300 management publications worldwide, as selected by an independent accreditation board of industry experts;" a "Literature Review" search of the journals in their collection, which turns up meta-analyses and systematic reviews, the abstracts of which neatly outline the purpose, methodology, and findings in each article; and the "Emerald Management First" selection aimed at managers. Their statement that "successful managers recognize the value of quality research and know that actions based on sound evidence beat those based on suspect intuition every time" sounds as though it comes directly from the EBMgt movement! However, since the content they provide is basically limited to their own publications, which do not include many important management research sources, this is not only an inadequate solution, it's a misleading one because there is little hint of what is missing. However, the format and the intent-providing a link between managers and researchers-are definitely on the right track.

Internet developments over the last few years, such as social networking, collaborative online projects, self-publishing, and OpenCourseWare, have not been ignored by businesspeople trying to share important information, or those trying to reach them. Witness: HRM Today (network.hrmtoday. com) a social networking site for human resources managers begun in 2008, with over 2000 members; HRSpace on Twitter (twitter.com/HRSpace) with over 5,400 followers; portal hr.com, offering links to its own articles, case studies, whitepapers, wikis, forums, polls and blogs; WikiProject Business where volunteer editors assess and improve on the 18,000
Wikipedia articles related to business. (The large majority rate $\mathrm{C}$ or below.) There is a vast and wide range of bloggers-from serious scholars to consultants and CEOs to everyman and everywoman, viz. www.hrworld.com/features/top-100-managementblogs-061008/, www.mbaexplorer.com/blog/2008/ 08/top-50-business-professor-blogs/, and blogs.hbr. org. Finally, universities and business schools are beginning to broadcast their lectures, and even entire courses, for free; MIT Sloan School of Management is the pioneer, with over 50 graduate courses available.

Another future consideration is the informationseeking behavior of the next decade's managers and faculty, as well as that of current students. A number of studies (Connaway, Radford, Dickey, De Angelis Williams, \& Confer, 2008; Rainie, 2006) have looked at the habits of "digital natives," as they enter the workplace and the academy, and who would be ready to enter management and scholarly ranks in 2016. This paradigm-shifting experience, of having grown up online, will impact all aspects of management practice and theory, but it will also affect how future generations look for, evaluate, and even create evidence. Rainie sees video games, for instance, which are played by virtually all college students today, as "the 'training program' for young workers that helps form their attitudes about the way the work-world operates - a world full of data streams, where analysis and decisions come at twitch speed, where failure at first is the norm, where the game player is the hero, and where learning takes place informally." How this will play out vis-à-vis the world of academic publishing in managementwhere recommendations are carefully considered and investigated, where success is what is aimed for, where the work of many is compared and consolidated, and where discourse is formulaic and codified-is something to think about.

\section{Recommendations Until the Future Arrives}

So in hindsight, having learned, since my days as a middle manager, about the utility and availability of scientifically based management advice, what could I have done-and what can other enlightened managers do now- to avail ourselves of it?

There are several ways that managers can find published research in articles and books. One is to ask your friendly local librarian for advice. Some excellent business libraries in the United States are public — namely the James J. Hill library in St. Paul, MN (www.jjhill.org/), New York Public Library's SIBL (www.nypl.org/locations/sibl), 
Boston's Kirstein Business Branch (www.bpl. org/research $/ \mathrm{kbb} / \mathrm{kbbhome}$.htm), the Library of Congress' Business Reference Service (www.loc. gov/rr/business/), and Brooklyn's Business Library (www.brooklynpubliclibrary.org/business/) —and many more cities in the United States and Canada have large sections of their public libraries devoted to business, entrepreneurship, and management. The British Library has a Business \& IP Centre in London, and has just launched an impressive Management and Business Library Portal (www.mbsportal.bl.uk) to "support the impact of research by making the findings of management research-from various sources-more readily available to working managers." Many university or community college libraries also keep their libraries open to everyone, with access to databases generally allowable from within the buildings. For small business owners in the United States, there are over 1,000 government-funded Small Business Development Centers (www.asbdc-us.org,) which are often connected to universities or business schools and can make use of their resources.

Taking this one step further, managers could, possibly through their professional associations, work with those libraries, universities, and business development organizations in their communities to enhance, support, and publicize those resources. This would work two ways: promoting the collections of research that exist to those who can make use of them, and providing some much-needed outside support to develop them further (or at least keep them from disappearing through today's imminent budget cuts.) This would also identify them as stakeholders in the advancement and dissemination of management science, further tying practitioners to research and its production.

Another way of finding published research would be to join forces with other managers, researchers, professors, and students locally and globally-in investigative and publishing collaborations, in executive training programs, in communities of practice, and even in social gatherings (Rynes, 2009). Taking advantage of burgeoning social networking technologies to do this would be a good way to connect and to leap over geographical boundaries. (Join the EBMgt Facebook page!) Participating in organizations dedicated to furthering management knowledge, such as the Academy of Management, SHRM, or, ideally, an EBMgt collaborative (Rousseau, 2007) will also provide both a forum for communication and a source of continued learning.
What can educators and researchers do to increase the visibility and accessibility of their research findings? For the former, professors can, as Giluk and Rynes say in their chapter 8 of this handbook, "help students become more informed consumers of research" with the intent that it will carry over into their lives as managers. In doing so, they can enlist the skills of their university librarians, information professionals who are immersed in how scholarly literature is organized and who regularly teach people to navigate it. (Speaking from personal experience, we are glad to be invited into the classroom.) They can also take advantage of the many suggestions offered in Leung \& Bartunek's chapter 9 of this volume, which enumerates many new communication tools available due to evolving new technologies.

To improve accessibility, researchers can also enlist in the "Open Access" movement by maintaining their right to self-archive their own work on their own web sites or in their university repositories, thus making it freely available despite being published in a subscription-based journal. This is done by selecting a journal for publishing one's work that makes this option contractually available. The SHERPARoMEO consortium, based at the University of Nottingham, keeps track of scholarly publishers' copyright policies; according to their data, out of 799 academic publishers, "63\% ... formally allow some form of self-archiving." (SHERPA-RoMEO, 2010.) A list of those is available on its web site, www.sherpa.ac.uk. Visibility is also enhanced in the process, as search engines such as Google Scholar readily locate and provide the articles in these archives. In fact, numerous studies "point to open access papers' being cited and consulted more often than toll-access work," which incidentally also serves promotion requirements for academics. (Willinsky, 2006.) Even better than simply participating would be to actively endorse and support this movement, in one's own university, in professional associations, and with colleagues. Federal legislation will push this substantially further, so all interested parties should voice support for the Federal Research Public Access Act of 2009.

The roadblock of "chaos" discussed earlier could be overcome by an organization taking on the responsibility of providing a single access route to reputable business research; this has been done in medicine with PubMed, in education with ERIC, and in psychology with PsycInfo, all of which are administered as not-for-profit enterprises by the National Library of Medicine, the U.S. Dept. 
of Education, and the American Psychological Association, respectively.

Libraries and librarians can help in various ways. Most academic libraries already champion Open Access, and many actively participate by undertaking the task of handling their university's repositories for faculty research. Academic librarians can contact management professors in their schools to offer their services as guides to finding research and developing search strategies - either by giving a class lecture, by being "embedded" in a course (as an on-call information expert), by creating online resource guides, or by offering a course like the Finding Evidence course developed by NYU librarians, described by Anthony Kovner in his chapter 10 of this volume. Public libraries for their part need to publicize their resources for businesses much more than they currently do, in order to increase their visibility, perhaps even engendering some corporate support for their continued existence.

The pace of change in the information industry is so breathtakingly fast that by the time this handbook is in print, much of this terrain will look different. This argues powerfully for speedy and resolute action on a major project to consolidate, clarify, publicize, and provide easy access to the valuable findings that are now buried in this hidden and costly avalanche of research. When that future does arrive, with roadblocks gone, our managers, students, and scholars alike will cruise down the evidence-based highway.

\section{References}

Alvarez, J. L., \& Mazza, C. (1998). Haute couture or pret-a-porter: Creating and diffusing management practices through the popular press. IESE Research Papers D/368. Retrieved from http://ideas.repec.org/p/ebg/iesewp/d-0368.html

Bennett, S. (2007). Campus cultures fostering information literacy. portal: Libraries and the Academy, 7(2), 147-167. doi:10.1353/pla.2007.0013

Blanchard, K. H., \& Johnson, S. (1982). The one minute manager. New York: Morrow.

Brin, Sergey. (2009). Official Google blog: The 2008 founders' letter. Retrieved March 1, 2011 from http://googleblog.blogspot.com/2009/05/2008-founders-letter.html

Buckingham, M., \& Coffman, C. (1999). First, break all the rules: What the world's greatest managers do differently. New York: Simon and Schuster.

Cascio, W. F. (2008). To prosper, organizational psychology should bridge application and scholarship. Journal of Organizational Behavior, 29(4), 455.

Case, D. O. (2008). Looking for information: A survey of research on information seeking, needs, and behavior (2nd ed.). London: Emerald Group Publishing.

Cason, C., \& Van Scoyoc, A. M. (2006). The electronic academic library: Undergraduate research behavior in a library without books. Portal: Libraries and the Academy, 6(1), 47-58. doi:10.1353/pla.2006.0012

Connaway, L. S., Radford, M. L., Dickey, T. J., De Angelis Williams, J., \& Confer, P. (2008). Sense-making and synchronicity: Information-seeking behaviors of millennials and baby boomers. Libri, 58(2), 123-135.

Durham, C. C., \& Bartol, K. M. (2004). Pay for performance. In E.A. Locke (Ed.), The Blackwell handbook of principles of organizational behavior (pp. 150-165). Malden, MA: Blackwell. Retrieved from http://books.google.com/

Furnham, A. (2000). Secrets of success from the Heathrow School of Management. Business Strategy Review, 11(3), 61-67.

Gibson, I., Goddard, L., \& Gordon, S. (2009). One box to search them all: Implementing federated search at an academic library. Library Hi Tech, 27(1), 118-133. doi:10.1108/07378830910942973

Griffiths, J. R., \& Brophy, P. (2005). Student searching behavior and the web: Use of academic resources and Google. Library Trends, 53(4), 539.

Housewright, R. (2009). Themes of change in corporate libraries: Considerations for academic libraries. portal: Libraries and the Academy, 9(2). Retrieved from http://muse.jhu.edu/journals/ portal_libraries_and_the_academy/v009/9.2.housewright. pdf

Housewright, R., \& Schonfeld, R. (2008). Ithaka's 2006 studies of keystakeholders in the digital transformation in higher education. Retrieved from http://www.ithaka.org/research/Ithakas $\% 20$ 2006\%20Studies $\% 20$ of\%20Key\%20Stakeholders $\% 20$ in $\% 20$ the $\% 20$ Digital\%20 Transformation $\% 20$ in $\% 20$ Higher\%20Education.pdf

Institute for the Future. (2002). Final synthesis report of the e-journal user study. Retrieved from http://ejust.stanford.edu/ SR-786.ejustfinal.html

Johnson, S. (1998). Who moved my cheese? An amazing way to deal with change in your work and in your life. New York: Putnam.

Kay, C. (2001). What do managers read? A survey of journals and periodicals used by lodging managers in the hospitality industry. Journal of Hospitality and Tourism Education, 13(3/4), 76-86.

Lencioni, P. (2002). The five dysfunctions of a team: A leadership fable. San Francisco, CA: Jossey-Bass.

Markides, C. (2007). In search of ambidextrous professors. Academy of Management Journal, 50(4), 762-768.

Marshall, J. (2009). Yahoo and Bing lose U.S. search share in November. ClickZ. Retrieved from http://www.clickz. com/3635900

Matarazzo, J., \& Pearlstein, T. (2007). Marrying two expert tools will help you sustain your corporate library. Library Journal Academic Newswire. Retrieved from http://www.libraryjournal.com/article/CA6407767.html

Miller, C. C. (2010). Amazon says e-books now top hardcover sales. The New York Times. Retrieved from http:// www.nytimes.com/2010/07/20/technology/20kindle. html?_r=1

Oder, N. (2009). ARL budget roundup: Large academic libraries face cuts in collections, staff, hours. Library Journal Academic Newswire. Retrieved from http://www.libraryjournal.com/ article/CA6655234.html

Odlyzko, A. (2002). The rapid evolution of scholarly communication. Learned Publishing, 15(1), 7-19.

Rainie, L. (2006). Digital natives invade the workplace. Pew Internet \& American Life Project. Retrieved from 
http://pewresearch.org/pubs/70/digital-natives-invade-theworkplace

Rich, M. (2010). Kindle books in snack sizes. New York Times. Retrieved from http://www.nytimes.com/2010/02/08/ business/media/08condense.html

Rousseau, D. M. (2007). A sticky, leveraging, and scalable strategy for high-quality connections between organizational practice and science. Academy of Management Journal, 50(5), 1037-1042.

Rousseau, D. M., \& McCarthy, S. (2007). Educating managers from an evidence-based perspective. Academy of Management Learning and Education, 6(1), 84-101.

Rynes, S. (2009). The research-practice gap in industrial-organizational psychology and related fields: Challenges and potential solutions. In S. Kozlowski (Ed.), Oxford handbook of industrial-organizational psychology. New York: Oxford University Press. Retrieved from http://papers.ssrn.com/ sol3/papers.cfm?abstract_id $=1455968$

Rynes, S. L., Colbert, A. E., \& Brown, K. G. (2002). HR professionals' beliefs about effective human resource practices: Correspondence between research and practice. Human Resource Management, 41(2), 149-174.

Shapiro, J. J., \& Hughes, S. K. (1996). Information literacy as a liberal art? Educom Review, 31, 31-35.

Shen, Y. (2007). Information seeking in academic research: A study of the sociology faculty at the University of WisconsinMadison. Information Technology and Libraries, 26(1), 4.
SHERPA. (2010). Statistics on publishers' copyright policies \& self-archiving. Retrieved from http://www.sherpa.ac.uk/ romeo/statistics.php

Suber, P. (2007). Open access overview. Retrieved from http:// www.earlham.edu/ $\sim$ peters/fos/overview.htm

Sutton, R. I. (2004). Prospecting for valuable evidence: Why scholarly research can be a goldmine for managers. Strategy \& Leadership, 32(1), 27.

Sutton, R. I. (2006). Management advice: Which $90 \%$ is crap? Change This. Retrieved from http://changethis.com/ manifesto/show/23.90PercentCrap

Tedd, L. A. (2005). E-books in academic libraries: An international overview. New Review of Academic Librarianship, 11(1), 57-79.

Terpstra, D. E., \& Rozell, E. J. (1997). Sources of human resource information and the link to organizational profitability. The Journal of Applied Behavioral Science, 33(1), 66.

Vermeulen, F. (2007). "I shall not remain insignificant": Adding a second loop to matter more. Academy of Management Journal, 50(4), 754-761.

Wells, C. (2006). Alumni access to research databases: The time is now. College \& Research Libraries News, 67(7), 413-416.

Wilbourne, S. (2001). The expanding ocean of difference between academic research and book publishing. Publishing Research Quarterly, 17(3), 29-32. doi:10.1007/s12109-001-0030-3

Willinsky, J. (2006). The access principle: The case for open access to research and scholarship. Cambridge, MA: MIT Press. 